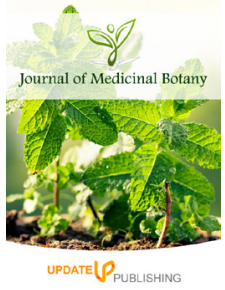

ISSN: $2521-3903$

\title{
Contribution to the knowledge of melliferous plants: Ethno apicultural survey with beekeepers in the district of Ziguinchor, Kolda and Sedhiou (Senegal)
}

\author{
Kady Diatta*, William Diatta, Alioune Dior Fall, Serigne Ibra Mbacké Dieng, \\ Amadou Ibrahima Mbaye, Emmanuel Bassène
}

Laboratory of Pharmacognosy and Botany, Cheikh Anta Diop University of Dakar, ZC 5005, FMPO, UCAD, Dakar, Fann, Senegal

\begin{abstract}
An ethno-apicultural survey was carried out for the plant species pollinated by honey bees in the green district of Casamance (South Senegal). This survey followed a well-established questionnaire concerning beekeepers in these areas. The listed melliferous flora was made of 61 species either. It's divided in 58 genus and 30 families though the most represented are in decreasing order Fabaceae with 12 species (19.67\%) followed by Rutaceae and Malvaceae with 4 species (6.55\% each), Arecaceae, Anacardiaceae, Combretaceae, Gramineae, Myrtaceae, with 3 species (4.91\% each), then Chrysobalanaceae, Lamiaceae, Meliaceae and Rubiaceae with 2 species (3.27\% each) and then Acanthaceae, Asteraceae, Canabaceae, Verbenaceae, Apocynaceae, Bignoniaceae, Annonaceae, Hymenocardiaceae, Icacinaceae, Lauraceae, Moringaceae, Musaceae, Celastraceae, Rhizophoraceae, Sapindaceae, Sterculiceae, Moraceae, Ochnaceae, with 1 species ( $1.63 \%$ each). Melliferous plants include $47.54 \%$ nectariferous plants followed by nectariferous polliniferous plants with $37.70 \%$ and finally polliniferous species with $14.75 \%$. This study enabled us to identify eight (08) species with high melliferous value. To enhance the value of these plants, further studies on foraging activity and nectar production will be led to prove their real melliferous potential.
\end{abstract}

Received: August 26, 2019

Accepted: March 16, 2020

Published: April 04, 2020

*Corresponding Author: Kady Diatta

Email:khadydiose@yahoo.fr

\section{INTRODUCTION}

The melliferous plants are plant species on which the bee takes substances, including nectar, pollen and resin to feed and to develop its various products (honey, royal jelly...). It is well known that the products of the hive reflect in quantity and quality the nature of the pollinated plants (Lafleche, 1981). In addition, melliferous plants vary with climatic conditions ( $\mathrm{G}$ de Layens, 1997). Indeed, Casamance includes three large districts with a very favorable climate for the development of plant species.

The area of classified forests is 607540 ha for 56 classified forests including 30 in Lower Casamance (116776 ha, Ziguinchor), 12 in Middle Casamance (84453 ha, Sedhiou) and 14 in Upper Casamance (396230 ha, Kolda). This potential allows the development of plant species, diversified and particularly honey. There are also mangroves that constitute specific plant formations. They enjoy the status of classified forests. This ecosystem is also home to many species of molluscs, fish, crustaceans, spiders, but especially bees (Geist, 2012).
Yet, there is undoubtedly in these forests classified considerable beekeeping resource, which should be developed not only to provide local people a high quality food supplement, but also to promote the growth of bee colonies and to provide agriculture and all vegetation a sufficient number of pollinators. Similarly, it is also important to develop beekeeping in these district because it represents a diversification of cash income source for the beekeeper and often impoverished rural community and no other type of resources (Ahouandjinou, 2016). The aim of this study is to determine the potentially honey plants to allow good conservation of these resources and a high quality beekeeping can solve the problem of malnutrition in indigenous peoples.

\section{MATERIALS AND METHODS}

\section{Study Area}

The survey was conducted in all three district. The Ziguinchor district has an area of $7339 \mathrm{~km}^{2}$, lies at $12^{\circ} 34^{\prime} 59^{\prime \prime} \mathrm{N}$ Latitude 
and $16^{\circ} 16^{\prime} 18$ "W Longitude with a population of 549151 peoples. It has a sub-Guinean climate and a total annual rainfall of $1190.1 \mathrm{~mm} / \mathrm{year}$. Then the district of Kolda with an area of $13721 \mathrm{~km}^{2}$, lies at 1304'60 " N Latitude and 14 ${ }^{\circ} 49^{\prime} 60$ ' W Longitude with a population of 847243 peoples. The climate is Guinean Sudano type with a total annual rainfall of $883 \mathrm{~mm} /$ year. Finally, the district of Sedhiou located at $12^{\circ} 42^{\prime} 29^{\prime \prime} \mathrm{N}$ Latitude and $15^{\circ} 33^{\prime 2} 4^{\prime \prime} \mathrm{W}$ Longitude has an area of 7330 $\mathrm{km}^{2}$ and a population of 452994 peoples. Sedhiou has a Sudano Guinean climate and The average annual rainfall is about $1000 \mathrm{~mm}$ (National Agency of Statistics and Demography, 2013). Beekeepers were interviewed about the different types of melliferous plants in their areas. Below representative map of the survey area (Map 1).

\section{RESULTS AND DISCUSSION}

A total of 61 plant species from 58 genera and 30 families were identified as melliferous plants. The families, botanical names, local names, nectariferous plants, nectariferous-polliniferous plants, polliniferous plants, biological type, biogeographic type, domestication type, beekeeping interest, flowering class, flowering period and quote percentage and uses are given in Table 1. The distribution of melliferous plants according to the biological type (Table 1) shows that the trees are the most represented 34/61 (55.74\%) followed by shrubs 19/61 (31.15\%) and herbs which is $7 / 61(11.5 \%)$ and finally lianas which represent 1/61 (1.66\%) are less than represented (Figure 1).

These results are according with those of Iritie et al., (2008) found $62.25 \%$ ligneous against $31.88 \%$ herbaceous and $6.88 \%$ liana, and with results from Dongock et al., (2004) who showed a higher rate of ligneous (trees, shurbs and shrubs) of $63.5 \%$ against $36.5 \%$ of herbaceous plants and with those of Nombré I, (2003) who found $52.8 \%$ of ligneous against $47.92 \%$ in Garanga and $57.37 \%$ of ligneous against $42.27 \%$ of herbaceous plants in Nazinga, Burkina Faso.
The melliferous flora is dominated by African and pan-tropical species which together account for nearly $86.88 \%$ of species (see Table I). Indeed, African species represent more than half of the species (57.38\%) while pantropical species have more than $1 / 3$ of the species. It has African species (57.38\%) pantropical species (29.51\%), Afro-Indian species (6.56\%), species from Africa and tropical America (3, 28\%), an Afro-Asian species (1.64\%) and an Asian American species (1.64\%) (Figure 2).

The dominance of the African species can be explained by the fact that African species are more adapted to the bioclimatic conditions of the environment than other species Noba et al., (2004). Several species are visited by bees according to beekeepers, of the herbaceous strata to the ligneous strata with fruit plant, cereal or agroforestry plants.

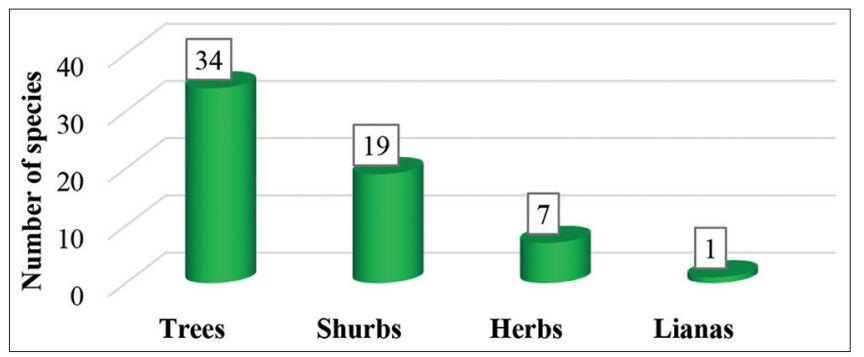

Figure 1: Distribution of plants according to their biological type

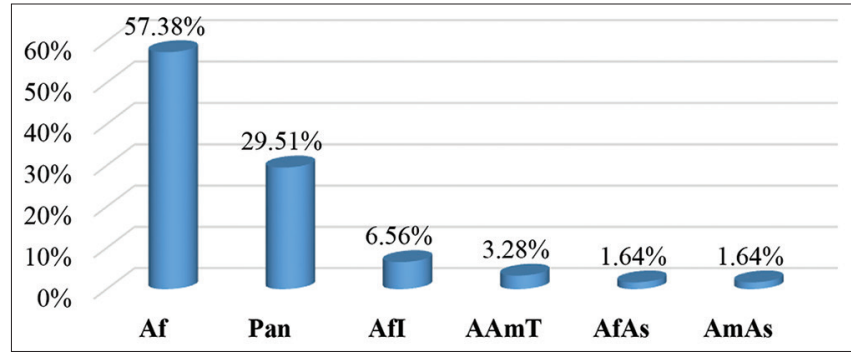

Figure 2: Distribution of plants according to their biogeographic type

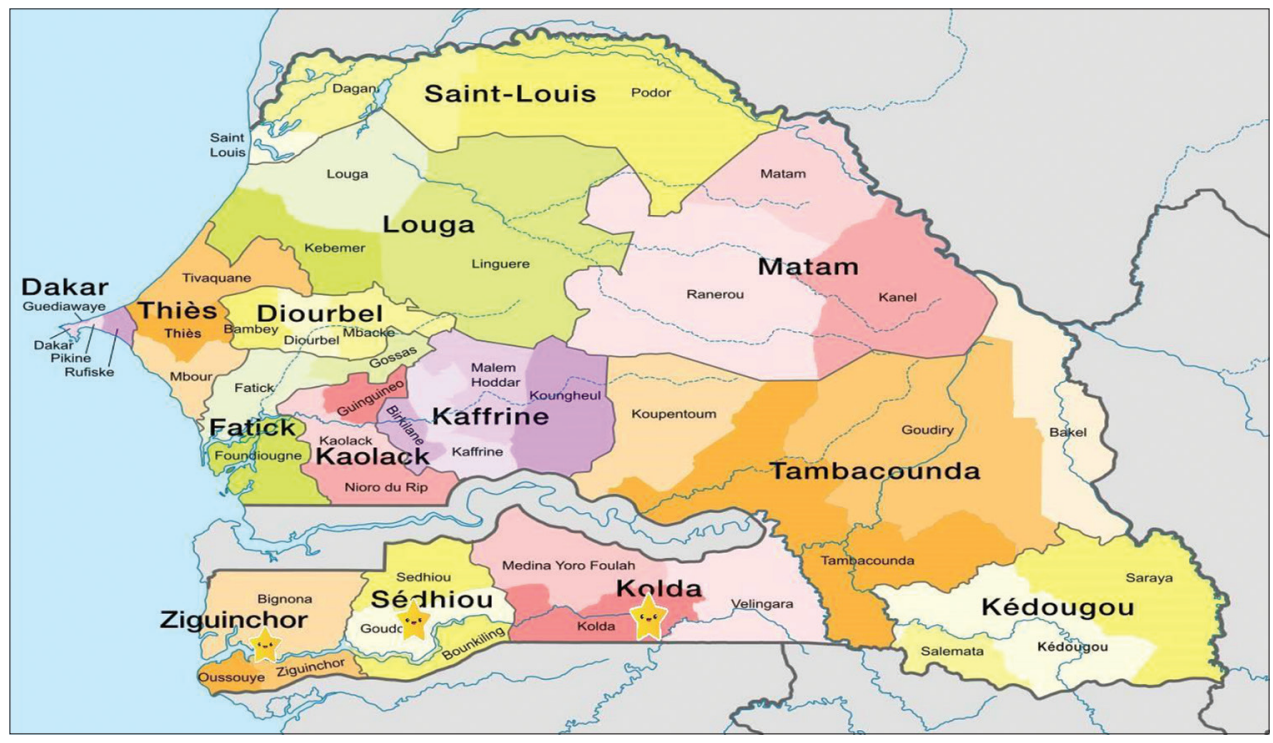

Map 1: Map of the survey area (Ziguinchor, Sedhiou et Kolda) 
Table 1: Summary of plants to data cited as melliferous

\begin{tabular}{|c|c|c|c|c|c|c|c|c|}
\hline Families/botanical name of plants & $\mathrm{LN}$ & BT & DT & BGT & AI & $\mathrm{FP}$ & $\mathrm{FC}$ & QP \\
\hline Adansonia digitata L. (MALVACEAE) & buy (W) & tree & spontaneous & Af & $\mathrm{N}$ & July-September & III & $13.7 \%$ \\
\hline Afzelia africana Sm. \& Pers (FABACEAE) & Bupaw $(d)$ & tree & spontaneous & Af & N & April & I & $94.10 \%$ \\
\hline Anacardium occidentale L. (ANACARDIACEAE) & bu kayu (d) & tree & cultivated & Pan & $\mathrm{N}$ & January -March & III & $100 \%$ \\
\hline Arachis hypogea L. Sp. (FABACEAE) & é tihé (d) & herb & cultivated & Pan & $\mathrm{N}$ & $\begin{array}{l}\text { August- } \\
\text { September }\end{array}$ & II & $29.4 \%$ \\
\hline Avicennia germinans Jacq. (ACANTHACEAE) & bu bèg $(d)$ & shurb & spontaneous & Pan & $\mathrm{N}$ & May -July & III & $94.1 \%$ \\
\hline Bombax costatum Pellegr. et Vuill. (MALVACEAE) & bu dimb (d) & tree & spontaneous & Af & NP & $\begin{array}{l}\text { November- } \\
\text { December }\end{array}$ & II & $62.7 \%$ \\
\hline $\begin{array}{l}\text { Borassus akeassi } \\
\text { Mart. (ARECACEAE) }\end{array}$ & si gumboudj (d) & tree & spontaneous & Af & $P$ & April & I & $64.7 \%$ \\
\hline Carapa procera DC. (MELIACEAE) & buhounoum & tree & cultivated & Pan & $\mathrm{N}$ & March-May & III & $17.6 \%$ \\
\hline Cassia sieberiana DC. (FABACEAE) & bu saét (d) & shurbs & spontaneous & Af & $\mathrm{P}$ & February- May & III & $76.5 \%$ \\
\hline Ceiba pentandra L. Gaertn. (MALVACEAE) & bu sana $(d)$ & tree & spontaneous & Pan & NP & December- January & II & $100 \%$ \\
\hline Celtis integrifolia Lam. (CANNABACEAE) & busingilit $(d)$ & tree & spontaneous & Afi & NP & April-June & III & $7.80 \%$ \\
\hline Citrus aurantium L. (RUTACEAE) & $\begin{array}{l}\text { bu } \\
\text { sorance (d) }\end{array}$ & shurbs & cultivated & Pan & $\mathrm{N}$ & August-September & II & $76.5 \%$ \\
\hline Citrus grandis L. & pamplemousse (f) & shurbs & cultivated & Pan & N & February-March & II & $78.4 \%$ \\
\hline Citrus limon L. (RUTACEAE) & lemouna (d) & shurbs & cultivated & Pan & $\mathrm{N}$ & August-October & III & $70.6 \%$ \\
\hline Cocos nucifera L. (ARECACEAE) & $\operatorname{coco}(w)$ & tree & cultivated & Pan & $P$ & October- November & II & $68.6 \%$ \\
\hline Cola cordifolia (Cav.) R. Br. (STERCULIACEAE) & boubeum $(d)$ & tree & spontaneous & Af & N & February & I & $33.3 \%$ \\
\hline $\begin{array}{l}\text { Combretum micranthum G. Don } \\
\text { (COMBRETACEAE) }\end{array}$ & buti & shu & spontaneo & Af & NP & June-A & II & $21.6 \%$ \\
\hline Daniellia oliveri (R.) Hutch. et Dalz. (FABACEAE) & bu sentignadio $(d)$ & tree & spontaneous & Af & $\mathrm{N}$ & January- March & III & $100 \%$ \\
\hline Delonix regia Boj. Raf. (FABACEAE) & flamboyant (f) & tree & cultivated & Pan & $\mathrm{N}$ & May-June & II & $31.4 \%$ \\
\hline Detarium senegalense J. Gmelin. (FABACEAE) & bu bunkut $(d)$ & tree & spontaneous & Af & N & July-September & III & $43.1 \%$ \\
\hline Dialium guineensis Willd. (FABACEAE) & bu falah (d) & tree & spontaneous & Af & N & October- January & III & $100 \%$ \\
\hline Elaeis guineensis Jacq. (ARECACEAE) & siit (d) & tree & cultivated & Pan & $P$ & All the year & III & $100 \%$ \\
\hline Eucalyptus sp. (MYRTACEAE) & hot bitél (w) & tree & cultivated & Pan & NP & July- August & II & $60.8 \%$ \\
\hline Faidherbia albida Del.Chev. (FABACEAE) & Boutafoul (d) & tree & spontaneous & Af & NP & January & I & $54.9 \%$ \\
\hline Ficus senegalensis Miq. (MORACEAE) & bu gang soto $(d)$ & tree & spontaneous & Af & NP & February & I & $5.9 \%$ \\
\hline Grewia bicolor Juss. (MALVACEAE) & Kel (w) & shurbs & cultivated & Afi & NP & June-July & II & $9.8 \%$ \\
\hline Guiera senegalensis j.f.gmel. (COMBRETACEAE) & bu funuk (d) & shurbs & spontaneous & Af & NP & April-June & III & $7.8 \%$ \\
\hline Hymenocardia acida Tul. HYMENOCARDIACEAE & bo sõnt (d) & tree & spontaneous & Af & NP & April-June & III & $41.2 \%$ \\
\hline Hyptis suaveolens Poit. (LAMIACEAE) & baïla sanké (d) & herb & spontaneous & AmAs & NP & August-October & III & $62.7 \%$ \\
\hline Icacina senegalensis A. Jussieu (ICACINACEAE) & furabang $(d)$ & shurb & spontaneous & Af & NP & January-May & III & $58.8 \%$ \\
\hline Khaya senegalensis A. Jussieu (MELIACEAE) & bu kay (d) & tree & cultivated & Af & N & April- May & II & $90.1 \%$ \\
\hline Lantana camara L. (VERBENACEAE) & $\begin{array}{l}\text { faux thé de } \\
\text { gambie }(f)\end{array}$ & shurbs & spontaneous & Pan & NP & February- April & III & $17.6 \%$ \\
\hline $\begin{array}{l}\text { Lepisanthes senegalensis (Juss. ex Poir.) Leenh } \\
\text { (SAPINDACEAE) }\end{array}$ & biéche (d) & tree & spontaneous & Af & N & April- may & II & $13.70 \%$ \\
\hline $\begin{array}{l}\text { Lophira lanceolata Van Tiegh. ex Keay } \\
\text { (OCHNACEAE) }\end{array}$ & é noun (d) & shurbs & spontaneous & Af & $\mathrm{N}$ & October- November & II & $19.6 \%$ \\
\hline Mangifera indica L. (ANACARDIACEAE) & bu $\mathrm{m}$ & tree & cult & Pan & $\mathrm{N}$ & Jar & III & $23.5 \%$ \\
\hline Moringa oleifera Lam. (MORINGACEAE) & nebed & shurbs & cultivated & Afi & $\mathrm{N}$ & May & III & $45.1 \%$ \\
\hline Musa sapientum L. (MUSACEAE) & gu nanar (d) & herb & cultivated & Pan & $\mathrm{N}$ & August- October & III & $25.5 \%$ \\
\hline Parinari excelsa Sabine (CHRYSOBALANACEAE) & $\operatorname{nini}(d)$ & tree & spontaneous & Af & N & March- April & II & $39.20 \%$ \\
\hline $\begin{array}{l}\text { Parinari macrophylla Sabine } \\
\text { (CHRYSOBALANACEAE) }\end{array}$ & biél (d) & tree & spontaneous & Af & N & March- May & III & $45.1 \%$ \\
\hline Newbouldia laevis (BIGNONIACEAE) & fugon & shurbs & eous & Af & $\mathrm{N}$ & $\mathrm{Ju}$ & I & $31.4 \%$ \\
\hline Oriza sativa L. (GRAMINEAE) & Mano (d) & herb & cultivated & Af A & $P$ & September & II & $43.1 \%$ \\
\hline Parkia biglobosa Jacq. Benth (FABACEAE) & $\begin{array}{l}\text { bu dilay (d); } \\
\text { oul (w) }\end{array}$ & tree & spontaneous & Af & NP & February -may & III & $94.1 \%$ \\
\hline Mill. (LAURACEAE) & avocatier (f) & shur & neous & AAT & $P$ & er-October & II & $3.9 \%$ \\
\hline Psidium guajava L. (MYRTACEAE) & $\begin{array}{l}\text { bi giab }(d) \\
\text { goyavier (f) }\end{array}$ & shurbs & cultivated & Pan & $\mathrm{N}$ & All the year & III & $13.7 \%$ \\
\hline Pterocarpus erinaceus Poir. (FABACEAE) & bu kon (d) & tree & spontaneous & Af & N & jan & III & $96 \%$ \\
\hline $\begin{array}{l}\text { Rhizophora racemosa G.F.W Mey. } \\
\text { (RHIZOPHORACEAE) }\end{array}$ & boum ah (d) & tree & cultivated & Pan & $\mathrm{N}$ & All the year & III & $76.5 \%$ \\
\hline Saba senegalensis DC. (APOCYNACEAE) & sidibasu (d) & Liana & spontaneous & Af & NP & All & III & $3.90 \%$ \\
\hline $\begin{array}{l}\text { Salacia senegalensis (Lam.) DC. } \\
\text { (CELASTRACEAE) }\end{array}$ & bu fumb (d) & tree & spontaneous & Af & NP & March- April & II & $11.70 \%$ \\
\hline $\begin{array}{l}\text { Sarcocephalus latifolius (Sm.) E.A.Bruce } \\
\text { (RUBIACEAE) }\end{array}$ & Birilo (d) & tree & spontaneous & Af & NP & February- March & II & $27.40 \%$ \\
\hline Senna alata L. (FABACEAE) & fu gagabu $(d)$ & shurbs & cultivated & Af & NP & July-August & II & $23.5 \%$ \\
\hline Sorghum bicolor $\mathrm{L}$. & baroute $(d)$ & herb & cultivated & Af & $P$ & October & I & $25.50 \%$ \\
\hline Spermacoce verticillata L. (RUBIACEAE) & é ribum $(d)$ & herb & cultivated & Af & NP & October November & II & $43.14 \%$ \\
\hline
\end{tabular}


Table 1: (Continued)

\begin{tabular}{|c|c|c|c|c|c|c|c|c|}
\hline Families/botanical name of plants & LN & BT & DT & BGT & $\mathrm{AI}$ & $\mathrm{FP}$ & $\mathrm{FC}$ & QP \\
\hline Spondias monbin L. (ANACARDIACEAE) & bu mobaye (d) & tree & spontaneous & AAT & $\mathrm{N}$ & April-may & II & $45 \%$ \\
\hline Syzygium guineense (Wild.) DC. (MYRTACEAE) & nanéli (d) & tree & cultivated & Af & NP & February-March & II & $21.6 \%$ \\
\hline Tamarindus indica L. (FABACEAE) & bu dahar (d) & tree & cultivated & AfI & NP & June- July & II & $72.5 \%$ \\
\hline $\begin{array}{l}\text { Terminalia macroptera Guill. Pers } \\
\text { (COMBRETACEAE) }\end{array}$ & bu ãnga (d) & tree & spontaneous & Af & NP & April-June & III & $24.5 \%$ \\
\hline Uvaria chamae P. Beauv. (ANNONACEAE) & bu ñañaru (d) & shurbs & spontaneous & Af & NP & June- August & III & $37.2 \%$ \\
\hline Vernonia colorata (Willd.) Drake (ASTERACEAE) & bu simbiya (d) & shurbs & spontaneous & Af & $P$ & January-March & III & $19.60 \%$ \\
\hline Vitex doniana Sweet. (LAM IACEAE) & buđink (d) & tree & spontaneous & Af & $\mathrm{N}$ & February-April & III & $72.5 \%$ \\
\hline Zanthoxylum zanthoxyloides Lam. (RUTACEAE) & ka sand $(d)$ & tree & spontaneous & Af & $\mathrm{N}$ & September & I & $33.30 \%$ \\
\hline Zea mays L. (GRAMINEAE) & Etoubabounio (d) & herb & cultivated & Pan & $P$ & June-September & III & $17.65 \%$ \\
\hline
\end{tabular}

AAT: Africa and tropical America, AmAs: American and asiatic, BT: biological type, FP: flowering period, Af: African species, N: nectariferous, BGT: biogeographic type, QP: quote percentage, AfI: Indian afro species, NP: nectariferous polliniferous, DT : domestication type, d: diola, Pan: pantropical species, P: polliniferous, AI: apicol interest, f: french, AfA: asiatic afro species, LN: locals names, FC: flowering class, w: wolof

The distribution of species according to the type of domestication showed the importance of spontaneous plants as melliferous plants in the study area. In fact, the large majority $(70.5 \%)$ of melliferous plants cited by beekeepers are spontaneous plants. These results are according to those found by Dongock et al., (2011) who found $57.9 \%$ spontaneous plants versus $42.1 \%$ cultivated, but did not according to those of Iritie et al. (2014) who found that cultivated plants were larger with $58 \%$ of the species recorded, and Dongock et al., (2004) and Pinta et al., (2001) showed respectively that $67.5 \%$ and $64 \%$ of the species identified in the field were cultivated.

Among the cultivated fruits, the most important are $38.9 \%$ corroborated by the results of Dongock et al., (2004) who found $28.5 \%$ of fruit on the $32.5 \%$ of cultivated species. Mangifera indica, Eucalyptus sp, Arachis hypogaea that were cited by beekeepers were listed by Dongock et al., (2004).

Natural or spontaneous plants are more represented because they have a better spatial distribution.

Regarding the distribution according to beekeeping interest, the results showed that the nectariferous taxa are more important with 29/61 (47.54\%), followed by taxa which were at the same time pollinated for their nectar and their pollen $(36.07 \%)$ and those visited only for their pollens (14.75\%). These results are in according to those of Nombré I, (2003) which showed a predominance of nectariferous taxa of $62.89 \%$ against $27.47 \%$ of nectariferous and polliniferous taxa and $9.89 \%$ of polliniferous taxa at Nazinga in Burkina Faso. These results correspond to those obtained by Bakenga et al., (2000), in Bukavu, the author shows that more than $2 / 3$ species are foraging for their nectar, they were not in agreement with those of Amakpé et al., (2015) found almost equal rates of nectariferous and polliniferous nectariferous taxa, which are $40.6 \%$ and $41.5 \%$, respectively, and its polliniferous taxon rate of $14.5 \%$ remains equal to that of our results was $14.75 \%$. They do not according to those of Yodomonhan et al., (2009) who found substantially equal rates of $31 \%$ nectariferous taxa, $35.6 \%$ nectariferous taxa and $33.3 \%$ polliniferous taxa.

The distribution of species according to the floral calendar: according to the time of flowering, the season from November to June consists exclusively of ligneous plants 47/61 (67.21\%), the rainy season from July to October all plants Herbs (Arachis hypogea, Musa sapientum, Oriza sativa, Sorghum bicolor, Zea mays, Hyptis suaveolens) and some ligneous species (Detarium senegalensis, Eucalyptus, Uvaria chamae, Zanthoxyllum zanthoxylloides, Citrus). The essential nectariferous flowers in the dry season with a month of March which corresponds to the first period of honeydew. According to Sawadogo et al., (2001) the other periods of the year which many other species grow correspond to honeydew of secondary importance. The evolution of the number of herbaceous species in flower over the months is similar to the results of Ramirez (2000) and Yodomonhan et al., (2009) for which the herbaceous plants begin their flowering as soon as the rains begin.

According to the flowering classes, species that have more than 2 months of flowering are more numerous with 30 species (49.18\%). By mixing the duration of flowering and beekeeping interest 30 species are intensely pollinated by bees and available for them for at least 2 months in course. Of these, $16(53.33 \%)$ are nectariferous, 11 (36.67\%) are nectariferous and polliniferous and $3(10 \%)$ are polliniferous. Taking into account the duration of flowering, three classes of melliferous species are obtained. Class I species with a flowering time of one month, class II of 2 months and class III of taxa with a flowering period of more than two months, come first with 30 species of flowering class III, (49.18\%), then class II flowering species with 22 species, $(30.06 \%)$ of the flora mentioned, and finally, class I which comprises 9 species, (14.75\%). Class III species are superior to those found by Yodomonhan et al., (2009) which is 34.5\%, but these Class II and I species are higher than the species found $34.5 \%$ and $31 \%$ against $30.06 \%$ and $14.75 \%$ respectively. The flowering of these plants, which is as well in the rainy season as in the dry season and therefore throughout the year, offers a good opportunity for the promotion of beekeeping activities in this area.

According to the citation percentage $16.39 \%$ of species are most cited by beekeepers for over $90 \%$ of these species and 5 are cited by all beekeepers as melliferous, these are: Elaeis guineensis, Ceiba pentandra, Anacardium occidentale, Daniellia oliveri, Dialium guineensis. 
In this species list cited as melliferous 6 were been already identified by Yodomonhan et al., (2009): Daniellia oliveri, Vernonia colorata, Hymenocardia acida, Syzygium guineensis, Grewia sp and Tamarindus indica. Sawadogo et al., (2001) had listed 4: Eucalyptus sp, Sorghum bicolor, Ceiba pentandra, Parkia biglobosa.

\section{CONCLUSION}

A total of 61 species were registered as melliferous plants. The information collected from this survey indicates that they are aware about of the presence of melliferous plants in their areas. This knowledge was inherited from their ancestors, but gradually disappears with the new generations who have abandoned the preservations of these forest resources. Most of the plant were wild and herbs, so their conservation is necessary for utilization of generations to come. This can be done by encouraging local people for the cultivation of these plants. Furthermore, this preliminary study may be act as a baseline for the discovery of new plant-based medicines but also for the implantation of apiaries for the production of honey. These melliferous species can be studied to know the compounds and these various activities.

\section{ACKNOWLEDGMENTS}

We thank all the beekeeping districts of Ziguinchor, Kolda and Sedhiou. In particular the Association of Planters of Diouloulou District (APAD) of the Rural Agricultural Promotion Center (CEPRA) and PADEC.

\section{REFERENCES}

Ahouandjinou STB, Yédomonhan H, Adomou AC, Tossou MG et Akoègninou $A$. Caractéristiques techniques et importance socioéconomique de l'apiculture au Nord-Ouest du Bénin: cas de la commune de Cobly. Int. J. Biol. Chem. Sci., 10 (3) (2016) 1350 - 1369. doi: http://dx.doi.org/10.4314/ijbcs.v10i3.35

Amakpé, Félicien GS, Akouehou, Dirk C, De Graaf, Brice Sinsin. Determination of the silvo-melliferous regions of Benin: a nationwide categorization of the land based on melliferous plants suitable for timber production, Journal of Agriculture and Rural Development in the Tropics and Subtropics, vol 116 N²,(2015), 143-156.

ANSD. Situation Economique et Sociale régionale (Ziguinchor, Sedhiou et Kolda) 2013.

Bakenga $\mathrm{M}$, Bahati $\mathrm{M}$ And Balagzi K. Inventaire des plantes mellifères de Bukavi et ses environs (Sud-Kivu, Est de la RDC), Tropicultura, $2000,18,89-93$.

Dongock ND, Tchoumboue J, Youmbi E, Zapfack L, Mapongmentsem P, \& Tchuenguem FFN. Inventaire et identification des plantes mellifères de la zone soudano-guinéene d'altitude de l'ouest Cameroun. Tropicultura, 2004, 22 (3), 139-145.

Dongock ND, Tchoumboue J, Youmbi E, Zapfack L, Mapongmentsem P, \& Tchuenguem FFN. Predominant melliferous plants of the western Sudano Guinean zone of Cameroon. African Journal of Environmental Science and Technology, 2011, 5 (6), 443-447.

Geist SJ, Nordhaus I, Hinrichs - Estuarine S, Coastal and Shelf Science. Occurrence of species-rich crab fauna in a human-impacted mangrove forest questions the application of community analysis as an environmental assessment tool Estuarine, Coastal and Shelf Science 96, 69-80.

G. De Layens et G. Bonnier, “Cours complet d'apiculture et conduite d'un rucher isolé», Editions Berlin, (1997).

Iritie BM, Eboua N, Wandan AA, Fantodji A, Abrogoua N, Gbomene LL. Identification des plantes mellifères de la zone agroforestière de l'école supérieure agronomique de yamoussoukro (côte d'ivoire) european scientific journal october 2014 edition vol.10, no.30 issn: 1857 - 7881 (print) e - issn 1857- 7431.

Lafleche B. Les abeilles. Guide pratique de l'apiculture amateur. Solar Nature, Paris, 1981, France, $76 \mathrm{p}$.

Noba K, Bâ AT, Caussanel JP, Mbaye MS, Barralis G. Flore adventice des cultures vivrières dans le sud du Bassin arachidier (Sénégal). Webbia, 2004, 59(2): 293-308.

Nombre I. Etudes des potentialités mellifères de deux zones du Burkina Faso: Garango (province du Bouglou) et Nazinga (province du Nahouri). Thèse de Doctorat d'Université, 2003, Université d'Ouagadougou, 156p.

Pinta JY, Tchoumboue J, Dongock N, Zango P \& Sitcheu G. Some characteristics of melliferous plants of the western High Lands of Cameroon. Proceedings of the $\mathrm{IX}^{\text {th }}$ annuel Conference of Bioscience, 2001, Yaoundé, Cameroun, 66 p.

Ramirez N. Reproductive phenology, life-forms, and habitats of the Venezuela Central Plain. American Journal of Botany, 2002, 89(2): 836-842.

Sawadogo M et Guinko S. Détermination des périodes de disponibilité et de pénurie alimentaires pour l'abeille Apis mellifica adansonii lat. dans la région ouest du Burkina Faso, 2001, J. Sci 1(2): 1-8.

Yedomonhan H, Tossou MG, Akoegninou A, Demenou BB et Traoré D. Diversité des plantes mellifères de la zone soudano-guinéenne: cas de l'arrondissement de Manigri (Centre-Ouest du Bénin), 2009, Int. J. Biol. Chem. Sci. 3(2): 355-366. 